National Marine

Fisheries Service

NOAA
Fishery Bulletin

a established in 1881 a
Spencer F. Baird

First U.S. Commissione of Fisheries and founder of Fishery Bulletin

\begin{abstract}
The distributions of sharks inhabiting deepwater ecosystems $(>200 \mathrm{~m})$ remain largely speculative because of limited collection efforts for species of relatively low commercial value and because of difficulties associated with sampling in deepwater habitats. As a result, ranges of deepwater shark species are often considered continuous across broad expanses despite records of occurrence, in many cases, being spatially fragmented. Within United States (US) waters of the western North Atlantic Ocean (WNA), the range of angel sharks (Squatinidae) in continental shelf and slope waters has been variously reported as both continuous and disjunct. The objective of this study was to use fishery-independent data to describe the range of angel sharks in US waters of the WNA and identify potential spatial discontinuities that could be consistent with the idea of multiple species or populations in the region. Results indicate that angel sharks in US waters of the WNA have a disjunct distribution and discontinuities occur from approximately Georgia through southern Florida and within a well-defined area off the coast of Louisiana. Evidence suggests spatial discontinuities could be related to thermal, salinity or current velocity barriers, or to a combination of these factors.
\end{abstract}

Manuscript submitted 2 July 2018. Manuscript accepted 13 September 2018. Fish. Bull. 116:337-347 (2018).

Online publication date: 2 October 2018. doi: 10.7755/FB.116.3-4.11

The views and opinions expressed or implied in this article are those of the author (or authors) and do not necessarily reflect the position of the National Marine Fisheries Service, NOAA.

\section{Distribution of angel sharks (Squatinidae) in United States waters of the western North Atlantic Ocean}

\author{
William B. Driggers III (contact author)' \\ Matthew D. Campbell ${ }^{1}$ \\ David S. Hanisko' ${ }^{1}$ \\ Kristin M. Hannan ${ }^{1}$ \\ Eric R. Hoffmayer ${ }^{1}$ \\ Christian M. Jones ${ }^{1}$ \\ Adam G. Pollack ${ }^{1}$ \\ David S. Portnoy² \\ Email address for contact author: william.driggers@noaa.gov \\ ${ }^{1}$ Mississippi Laboratories \\ Southeast Fisheries Science Center \\ National Marine Fisheries Service, NOAA \\ P.O. Drawer 1207 \\ Pascagoula, Mississippi 39567 \\ 2 Marine Genomics Laboratory \\ Department of Life Sciences \\ Texas A\&M University-Corpus Christi \\ 6300 Ocean Drive \\ Corpus Christi, Texas 78412
}

\begin{abstract}
shark species are often considered continuous across broad expanses despite occurrence records being spatially fragmented.

Within United States (US) waters of the western North Atlantic Ocean (WNA), sharks from the orders Hexanchiformes, Squaliformes, Lamniformes, Squatiniformes, and Carcharhiniformes occur in benthic habitats of the outer continental shelf and slope (Castro, 2011). Of these fishes, angel sharks are of particular concern because the family Squatinidae is reported to be the most threatened family of sharks globally (Dulvy et al., 2014). Conservation concern for angel sharks results from high bycatch rates, regional extinctions, relatively $k$ selected life history characteristics, data deficiencies (e.g., Colonello et al., 2007; Baremore, 2010; Tagliafico et al., 2017), and, importantly, the
\end{abstract}




\section{Table 1}

Data sources for trawl surveys used to examine the spatial distribution of squatinid sharks in the western North Atlantic Ocean. Data were collected by the Marine Resources Monitoring, Assessment, and Prediction Program (MARMAP), the Northeast Area Monitoring and Assessment Program (NEAMAP), the Northeast Fisheries Science Center (NEFSC), Southeast Area Monitoring and Assessment Program South Atlantic (SEAMAP-SA) and Gulf of Mexico (SEAMAP-GOM) surveys, the Southeast Fisheries Science Center (SEFSC) Small Pelagics/Acoustic Trawl Survey, and SEFSC Mississippi Laboratories historical and exploratory trawl surveys (MSLABS). $n=$ the total number of trawls conducted over each time series.

\begin{tabular}{|c|c|c|c|c|c|}
\hline Data source & Years & Months sampled & $n$ & Spatial coverage & Depth $(\mathrm{m})$ \\
\hline MARMAP & $1973-1980$ & Jan-Nov & 1196 & Cape Hatteras, NC, to Cape Canaveral, FL & $3-108$ \\
\hline NEAMAP & $2007-2016$ & Apr-May, Sep-Nov & 2870 & Cape Cod, MA, to Cape Hatteras, NC & $4-57$ \\
\hline NEFSC & $1963-2016$ & Jan-Dec & 43,121 & Halifax, Nova Scotia, to Cape Canaveral, FL & $2-1164$ \\
\hline SEAMAP-SA & 1989-2015 & Apr-Nov & 16,046 & Cape Hatteras, NC, to Cape Canaveral, FL & $2-20$ \\
\hline MSLABS & $1950-1997$ & Jan-Dec & 29,392 & Rhode Island to Brownsville, TX & $4-3085$ \\
\hline SEAMAP-GOM & $1987-2016$ & Jun-Jul, Oct-Nov & 16,794 & Key West, FL, to Brownsville, TX & $2-113$ \\
\hline SEFSC & $2002-2016$ & Oct-Nov & 1538 & Key West, FL, to Brownsville, TX & $12-555$ \\
\hline
\end{tabular}

limited spatial distribution of some species (Compagno et al., 2005). For example, Walsh and Ebert (2007) confirmed the validity of 4 species of squatinids around Taiwan in the western North Pacific Ocean: Taiwan angel shark (Squatina formosa); Japanese angel shark (S. japonica), clouded angel shark (S. nebulosa); and ocellated angel shark (S. tergocellatoides). Similarly, Vaz and de Carvalho (2013) described the overlapping range of three sympatric squatinids within the western South Atlantic Ocean off the coast of Brazil: Argentine angel shark (S. argentina); angular angel shark $(S$. guggenheim); and hidden angel shark (S. occulta).

Angel sharks inhabiting the WNA off the US east coast of the US (EC) and throughout the Gulf of Mexico (GOM) are largely thought to consist of a single species, the Atlantic angel shark (S. dumeril) (e.g., Bigelow and Schroeder, 1948; Castro, 1983; Compagno, 1984). However, Applegate et al. (1979) reported the possible presence of an undescribed squatinid in the GOM on the basis of a specimen collected in a fish market in Mexico. Later, Castro-Aguirre et al. (2006) described 2 new species of angel sharks, Gulf angel shark (S. heteroptera) and Mexican angel shark ( $S$. mexicana), from the GOM. Shortly thereafter, Ebert et al. (2013) placed the 2 newly described species in synonymy with $S$. $d u$ meril leaving the validity of these species in question, a conclusion supported by Eschmeyer and Fricke ${ }^{1}$ but in disagreement with Castro (2011). Despite the taxonomic uncertainty associated with angel sharks in the GOM, the range of Atlantic angel sharks in continental shelf and slope waters of the WNA has been reported as continuous by some and disjunct by others. For example, Compagno (2002) indicated angel sharks within the WNA have a continuous range from Massachusetts to Veracruz, Mexico, whereas Bigelow and Schroeder

\footnotetext{
${ }^{1}$ Eschmeyer, W. N., and R. Fricke (eds.). 2017. Cata$\log$ of fishes. Electronic version, updated 1 November 2017. [Available from website,]
}

(1948) reported that the range extends from southern New England to North Carolina off the east coast and from the Florida Keys into the northern GOM.

On the basis of conflicting information regarding the range of the genus in US waters of the WNA, our goal was to examine fishery-independent data collected throughout the region to determine the distribution of angel sharks. Our goal was 1) to determine whether the range is continuous (or discontinuous) throughout US waters of the WNA and 2) to identify spatial discontinuities in distribution that could be consistent with the idea of multiple species or populations in the region.

\section{Materials and methods}

To examine the broad- scale distribution of squatinids in US waters of the WNA, catch data from 7 fishery-independent trawl surveys were obtained and analyzed. Data were collected from Nova Scotia to the Florida Keys off the EC and in the northern GOM from the Florida Keys to Brownsville, Texas. The boundary between the EC and the GOM was designated to be at $81.0^{\circ} \mathrm{W}$. All data sources were trawl based; however, because of a lack of consistency in survey design and gear configurations among and, in some cases, within data sources, we did not compare relative abundance (i.e., catch-per-unit-of-effort) throughout the sampling area. Additionally, because of numerous changes in the experimental design and gear of most surveys, research design and gear specifications are not provided in the present study. Data sources from the east coast of the US included the 1) National Marine Fisheries Service (NMFS), Northeast Fisheries Science Center (NEFSC), Spring, Autumn and Winter Bottom Trawl surveys (1963-2016); 2) the Northeast Area Monitoring and Assessment Program (NEAMAP) (2007-2016) Survey; 3) the joint South Carolina Department of Nat- 


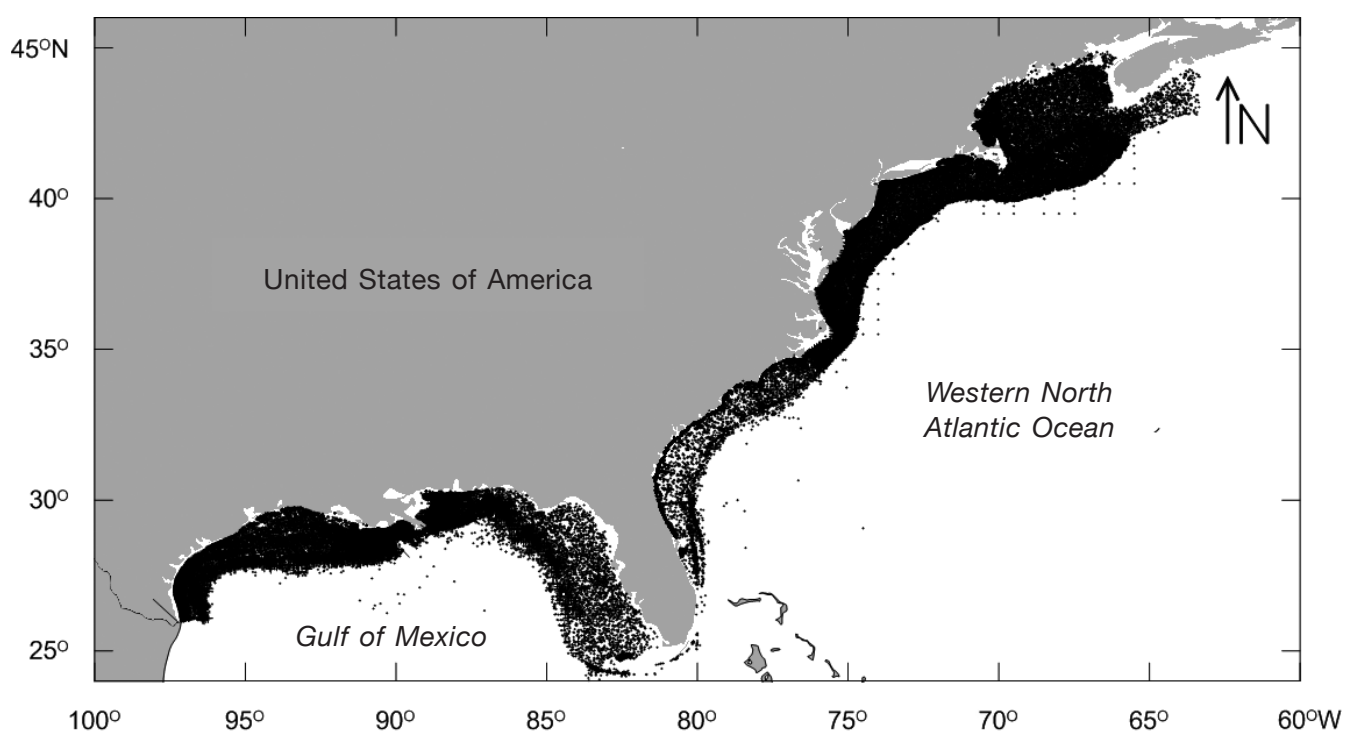

Figure 1

Locations of 104,957 trawls conducted during 7 fishery-independent surveys in the western North Atlantic Ocean between 1950 and 2016. Black dots represent a single sampling station, and many dots overlap because of high sampling density, most notably in the northern and western parts of the sampling area.

ural Resources and NMFS, Marine Resources Monitoring, Assessment, and Prediction (MARMAP) Survey (1973-1980); and 4) the Southeast Area Monitoring and Assessment Program-South Atlantic (SEAMAPSA) Survey (1989-2015); and 5) NMFS, Mississippi Laboratories historical and exploratory trawl surveys (MSLABS) (1950-1997). Data collected from the GOM included the 1) MSLABS surveys, 2) the SEAMAPGOM Survey (1982-2014), and the 3) NMFS, Southeast Fisheries Science Center, Small Pelagics/Acoustics Trawl Survey (2002-2014) (Table 1).

The position of each trawl and the locations where angels sharks were captured were plotted to determine the distribution of squatinids within the surveyed area. Median depth and depth distributions of all trawls conducted and locations where angel sharks were captured were compared for both regions by using Mann-Whitney-Wilcoxon (W) and Kolmogorov-Smirnov (K-S) tests, respectively. Results of the K-S test were used in conjunction with histograms to determine whether angel sharks were uniformly distributed throughout sampled depths. Additionally, bottom temperature and salinity (measured according to the practical salinity scale) information were available for a subset of the data and were compared, by using W and K-S tests, to determine whether these abiotic factors significantly affect the distribution of angel sharks in the two areas. To describe region-specific depth, temperature, and salinity preferences, the upper and lower quartiles are presented for each variable, as suggested by Magnuson et al. (1979) for skewed data. Logistic regression was used to examine the relationship between binomial catch (i.e., no catch versus positive catch), depth, temperature, and salinity. Because of a significant col- linearity between depth and temperature within some seasons, logistic models were run that included and excluded depth.

Data were obtained from the NOAA National Centers for Environmental Information (Boyer et al. ${ }^{2}$; Seidov et al. ${ }^{3}$ ) to generate maps of bottom temperature and salinity off the southeastern EC and throughout the GOM in order to visualize potential barriers to movements between the two regions. Mean values for both variables were obtained for grids of $1 / 10^{\circ}$ latitude by $1 / 10^{\circ}$ longitude and plotted with ArcGIS ${ }^{4}$ software, vers. 10.3.1 (Esri, Redlands, CA). Temperature data were limited to winter months (i.e., January, February and March), whereas salinity data was pooled over all months.

\section{Results}

Data were obtained from 104,957 trawls conducted from Nova Scotia to the Florida Keys $(n=66,161)$ and throughout the northern GOM ( $n=38,796)$ (Fig. 1). Off

\footnotetext{
${ }^{2}$ Boyer, T. P., M. Biddle, M. Hamilton, A. V. Mishonov, C. Paver, D. Seidov, and M. Zweng. 2015. Gulf of Mexico regional climatology (NCEI accession 0123320). Vers. 1.1. NOAA Natl. Cent. Environ. Inf. Data set. [Available from website, accessed March 2018.]

${ }^{3}$ Seidov, D., O. K. Baranova, D. R. Johnson, T. P. Boyer, A. V. Mishonov, and A. R. Parsons. 2016. Northwest Atlantic regional climatology, Regional Climatology Team (NCEI accession 0155889). Vers. 1.1. NOAA Natl. Cent. Environ. Inf. Data set. website, accessed March 2018.]

${ }^{4}$ Mention of trade names or commercial companies is for identification purposes only and does not imply endorsement by the National Marine Fisheries Service, NOAA
} 

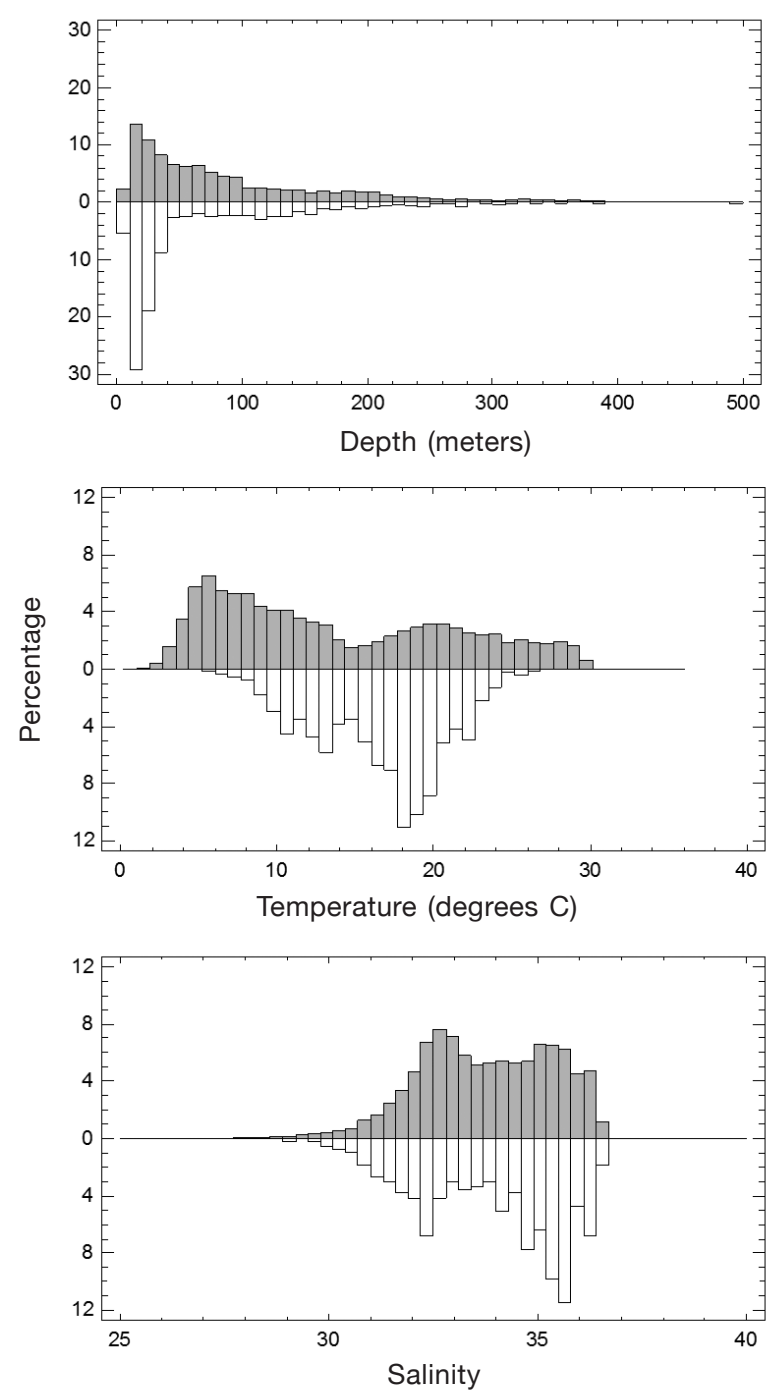

Figure 2

Comparison of depth $(<500 \mathrm{~m})$, temperature, and salinity $(>24)$ at all sampled locations (gray bars) and at locations where angel sharks (Squatinidae) were collected (white bars) off the East Coast of the United States between 1950 and 2016, expressed as percentages of total number of trawls conducted $(N=49,887)$ and trawls in which angel sharks were captured $(n=1001)$.

the EC, trawls were conducted from $24.67^{\circ}$ to $44.87^{\circ} \mathrm{N}$ at depths from 3.7 to $3840.0 \mathrm{~m}$ (mean: $92.07 \mathrm{~m}$ [standard error (SE) 0.46]) and 89 trawls were conducted at depths greater than $500 \mathrm{~m}$ (Fig. 2). In the GOM, trawls were conducted at depths from 1.8 to $3085.2 \mathrm{~m}$ (mean: $62.07 \mathrm{~m}$ [SE 0.54]) and 49 trawls were conducted at depths greater than $1000 \mathrm{~m}$ (Fig. 3). In both regions, sampling occurred in all months; however, effort was lowest during January, February, and December (Fig. 4). A total of 4999 angel sharks were collected during the trawl surveys; 2465 were caught off the EC and

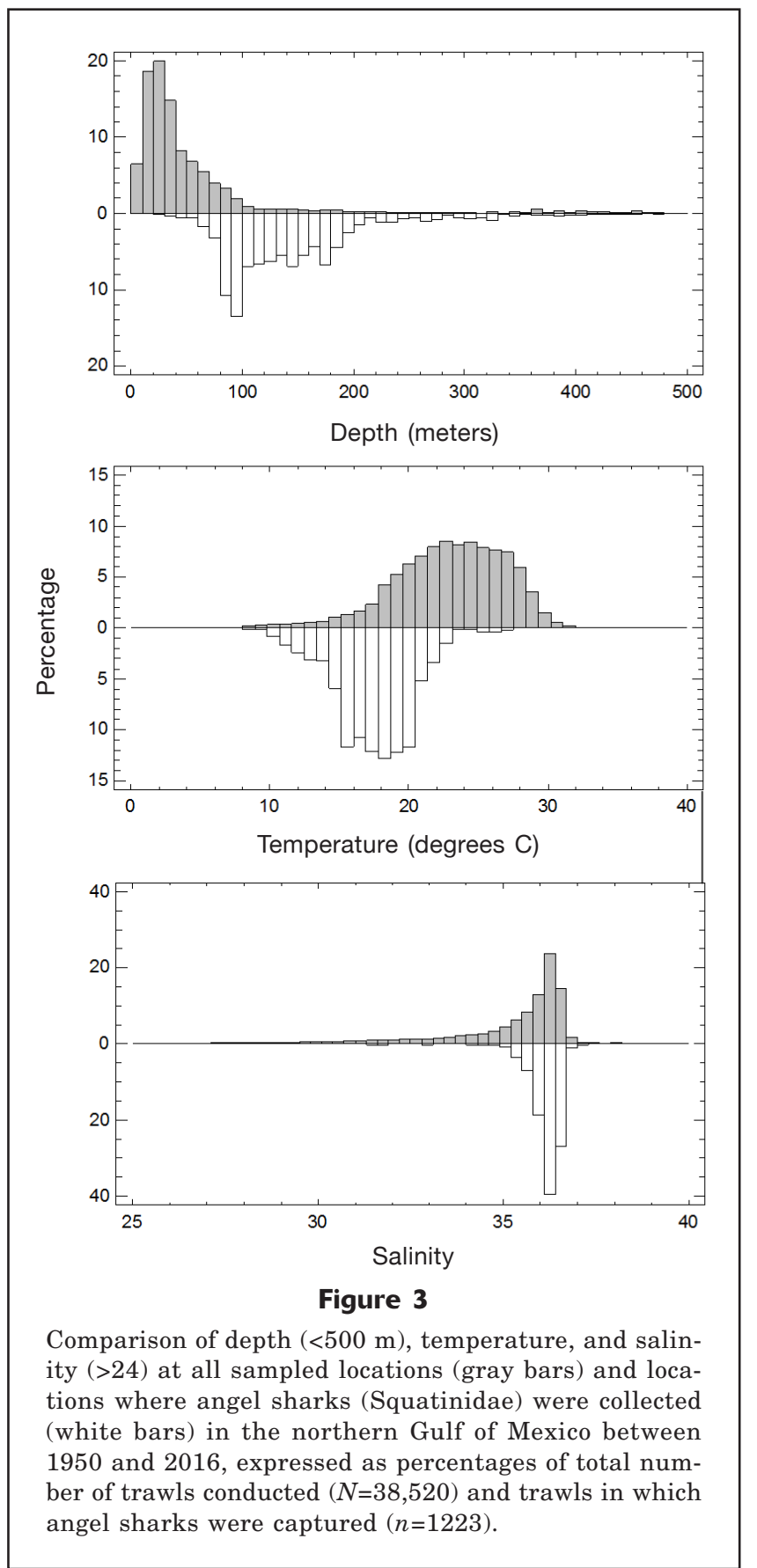

2534 were captured in the GOM. Angel sharks were collected off the EC from $32.93^{\circ}$ to $39.29^{\circ} \mathrm{N}$ at depths between 5.4 and $494.0 \mathrm{~m}$ (Figs. 2 and 5). Off the EC there was a significant difference in the distribution of depths sampled and depths where angel sharks were collected (K-S statistic: 8.92, $P<0.01$ ). Angel sharks were captured at higher rates at depths less than $\sim 60$ $\mathrm{m}$ and between 100 and $160 \mathrm{~m}$ than would be expected if their spatial distribution were uniform (Fig. 2).

In the GOM, angel sharks were collected at depths between 25.6 and $473.6 \mathrm{~m}$; however, only $2.2 \%$ of indi- 


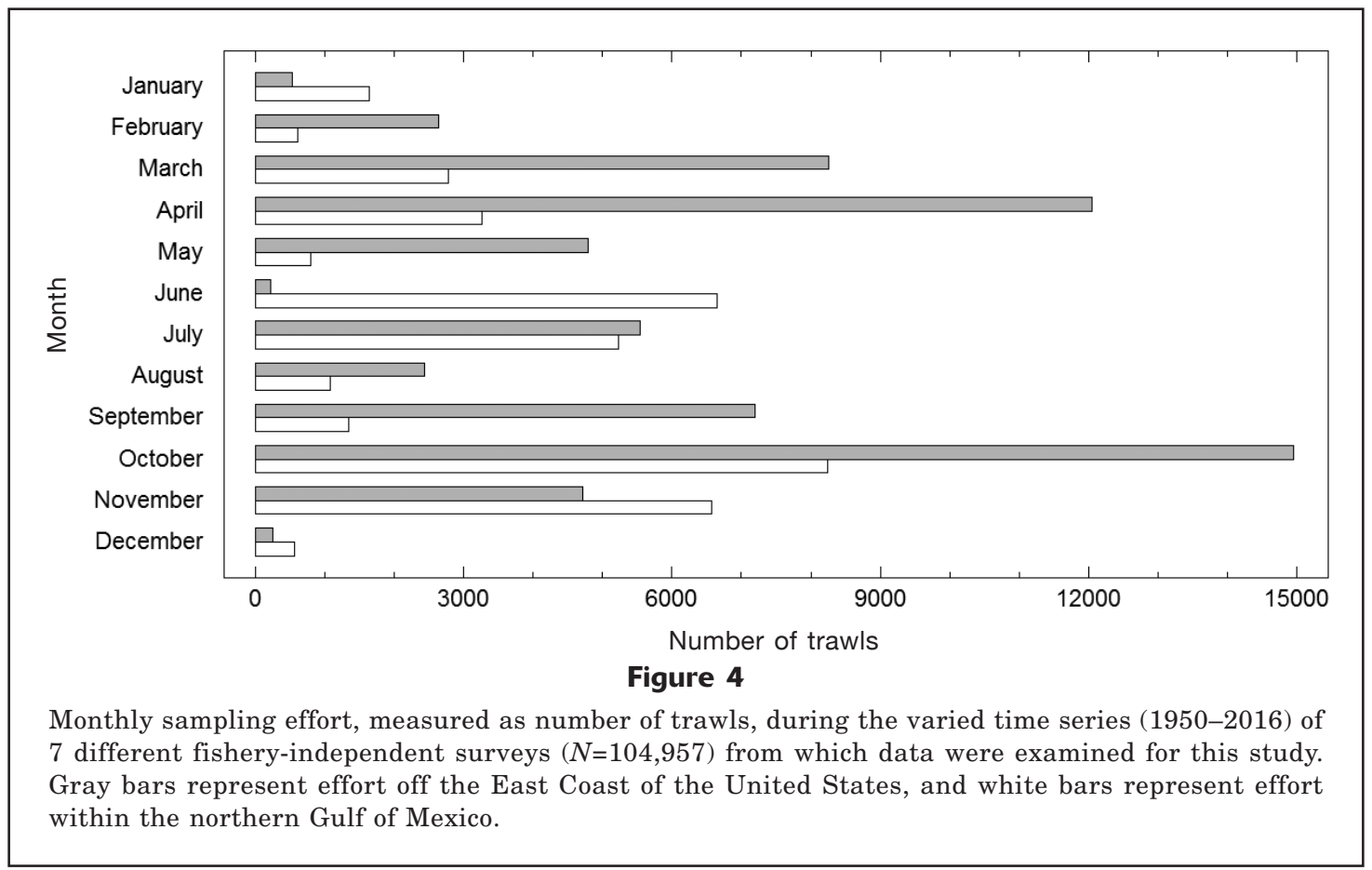

viduals were collected at a depth less than $70 \mathrm{~m}$, despite that $80.0 \%$ of the total trawling effort occurred in shallower water. There was a significant difference in the distributions of depths sampled and depths where angel sharks were collected in the GOM (K-S statistic: $26.93, P<0.01$ ), and no individuals were captured at depths less than $25 \mathrm{~m}$. However, $97.8 \%$ of individuals were caught between 70 and $474 \mathrm{~m}$ where $19.2 \%$ of the total sampling effort occurred (Fig. 3). The distribution of squatinids was relatively continuous throughout outer continental shelf waters of the GOM; however, only 2 individuals were observed between the Mississippi River Delta and the western boundary of the Mississippi Canyon ( 150 linear km, Fig. 5), despite 3600 trawls that were conducted within this area. The 2 sharks were caught in 1950 and 1951 at depths of $73.1 \mathrm{~m}$ and $82.3 \mathrm{~m}$, respectively, east of Mississippi Canyon.

Angel sharks off the EC $\left(13.5-19.5^{\circ} \mathrm{C}\right)$ and in the GOM $\left(15.7-19.4^{\circ} \mathrm{C}\right)$ were collected in relatively cool waters and showed similar temperature preferences (median preferred temperature for $\mathrm{EC}=17.5^{\circ} \mathrm{C}$, median for the $\mathrm{GOM}=17.6^{\circ} \mathrm{C}$ ) (Table 2; Figs. 2 and 3). Depth preference for angel sharks was deeper in the GOM $(92.3-171.9 \mathrm{~m}$; minimum depth observed=25.6 $\mathrm{m})$ than off the EC (17.0-94.0 m; minimum depth observed=5.4 m) (Table 2). Of the sharks captured that had corresponding salinity data available, only 7 out of 2266 individuals were collected in brackish water (salinity <30.0). In both regions, angel sharks indicated a preference for high salinity (Table 2; Figs. 2 and 3); however, sharks were caught over a broader range of salinity off the EC.
There were 20,566 stations off the EC and 18,116 stations in the GOM that had a full complement of depth, temperature, and salinity data. Within the GOM, there was a significant relationship between temperature $\left(\chi^{2}=437.76, P<0.01\right)$, salinity $\left(\chi^{2}=387.05, P<0.01\right)$, and positive catch (deviance=2220.71, $P<0.01$ ); however, depth was not significant when included in the logistic model $\left(\chi^{2}=0.03, P=0.87\right)$. When excluding depth from the model, the relationship between temperature $\left(\chi^{2}=1725.18, P<0.01\right)$, salinity $\left(\chi^{2}=391.06, P<0.01\right)$, and positive catch remained significant (deviance $=2223.75$, $P<0.01)$. Similarly, off the EC, there was a significant relationship between temperature $\left(\chi^{2}=420.35, P<0.01\right)$, salinity $\left(\chi^{2}=89.82, P<0.01\right)$, and positive catch (deviance $=658.72, P<0.01)$; however, depth $\left(\chi^{2}=1.12, P=0.29\right)$ was not a significant factor. The relationship between temperature $\left(\chi^{2}=420.35, P<0.01\right)$, salinity $\left(\chi^{2}=89.82\right.$, $P<0.01$ ), and positive catch remained significant when depth was not included as a factor (deviance $=658.72$, $P<0.01$ ). Visual inspection of mapped abiotic conditions in the sampled region indicated that relatively high temperatures associated with waters off the southern Florida peninsula during the winter could represent a barrier to movements of squatinids between the EC and GOM (Fig. 6). There was no indication of a barrier to movements between the EC and the northern GOM in relation to salinity (Fig. 7).

\section{Discussion}

All current sources describing the distribution of Atlantic angel sharks off the EC list the species as oc- 


\section{Table 2}

Abiotic characteristics of bottom water associated with all stations sampled and stations where squatinid sharks were captured in waters along the East Coast (EC) of the United States and throughout the northern Gulf of Mexico (GOM) over varied time series during 1950-2016. All $P$-values for the Mann-Whitney-Wilcoxon (W) and Kolmogorov-Smirnov (K-S) tests were less than 0.01. Mean values are given with standard errors (SEs).

\begin{tabular}{|c|c|c|c|c|c|c|c|c|}
\hline Variable & $n$ & Range & $\begin{array}{c}\text { Mean } \\
(\mathrm{SE})\end{array}$ & $\begin{array}{c}\text { Lower } \\
\text { quartile }\end{array}$ & $\begin{array}{c}\text { Upper } \\
\text { quartile }\end{array}$ & Median & W & $\mathrm{K}-\mathrm{S}$ \\
\hline \multicolumn{9}{|l|}{ Depth (m) } \\
\hline EC all stations & 49,976 & $3.7-3840.0$ & $92.07(0.46)$ & 28.0 & 128.0 & 64.0 & $1.81 \mathrm{E}+07$ & 8.92 \\
\hline EC sharks present & 1001 & $5.4-494.0$ & $61.86(2.13)$ & 17.0 & 94.0 & 28.0 & & \\
\hline GOM all stations & 38,789 & $1.8-3085.2$ & $62.07(0.54)$ & 20.1 & 60.4 & 32.9 & $4.27 \mathrm{E}+07$ & 26.93 \\
\hline GOM sharks present & 1223 & $25.6-473.6$ & $144.3(1.96)$ & 92.3 & 171.9 & 128.6 & & \\
\hline \multicolumn{9}{|l|}{ Temperature $\left({ }^{\circ} \mathrm{C}\right)$} \\
\hline EC all stations & 56,273 & $-1.4-30.71$ & $13.75(0.03)$ & 7.1 & 20.2 & 11.8 & $3.26 \mathrm{E}+07$ & 10.94 \\
\hline EC sharks present & 907 & 5.5-26.7 & $16.72(0.13)$ & 13.5 & 19.5 & 17.5 & & \\
\hline GOM all stations & 19,665 & $6.1-39.1$ & $22.94(0.03)$ & 20.4 & 26.0 & 23.3 & $2.25 \mathrm{E}+06$ & 18.89 \\
\hline GOM sharks present & 899 & $8.5-26.7$ & $17.47(0.09)$ & 15.7 & 19.4 & 17.6 & & \\
\hline \multicolumn{9}{|l|}{ Salinity } \\
\hline EC all stations & 36,550 & $22.1-37.8$ & $33.75(0.01)$ & 32.6 & 35.1 & 33.8 & $1.06 \mathrm{E}+07$ & 3.19 \\
\hline EC sharks present & 530 & $22.1-36.5$ & $34.02(0.08)$ & 32.5 & 35.5 & 34.5 & & \\
\hline GOM all stations & 18,026 & $2.3-38.0$ & $36.13(0.02)$ & 34.7 & 36.3 & 35.9 & $1.09 \mathrm{E}+07$ & 9.64 \\
\hline GOM sharks present & 879 & $28.8-37.4$ & $36.13(0.02)$ & 36.0 & 36.4 & 36.3 & & \\
\hline
\end{tabular}

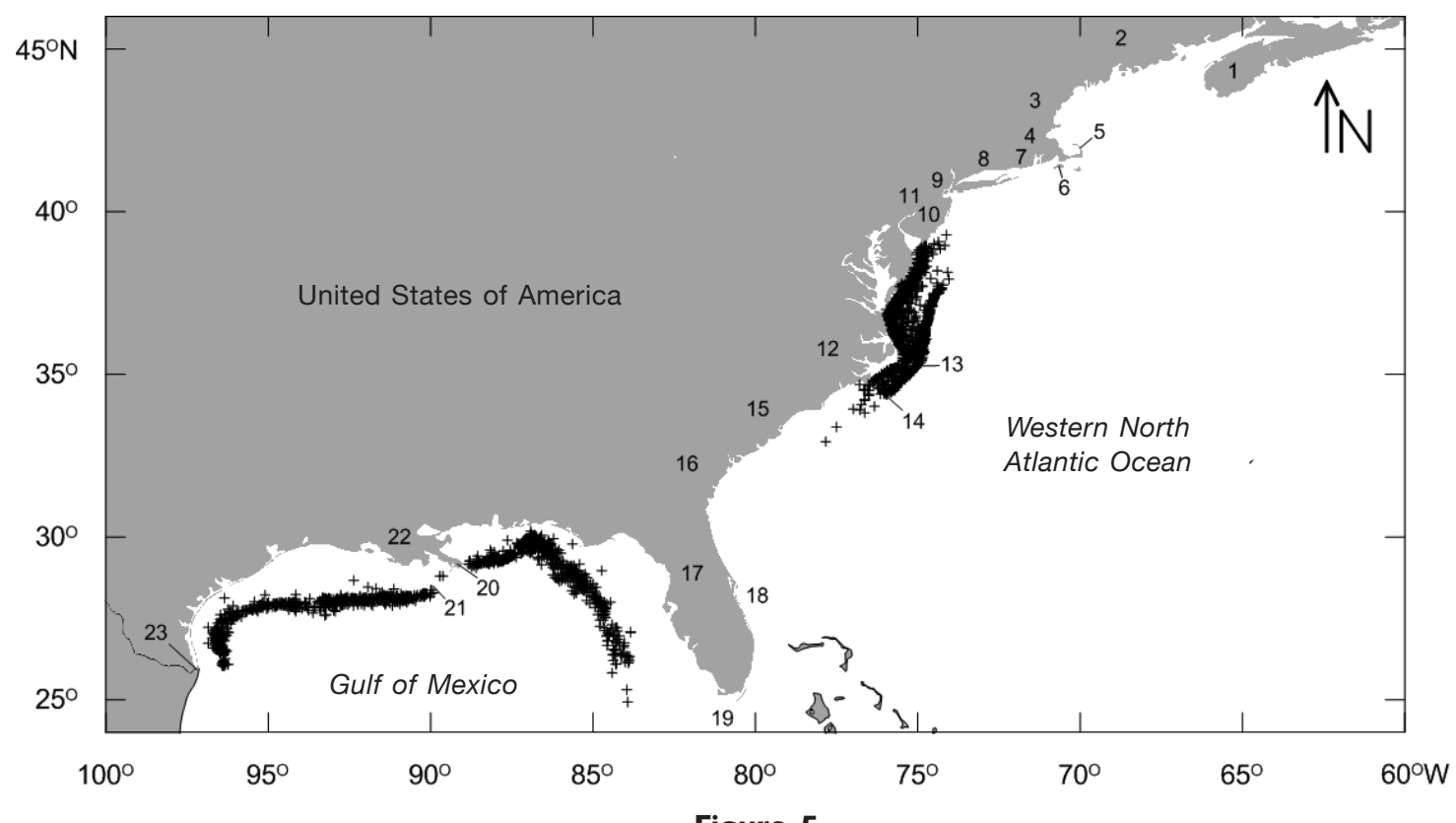

Figure 5

Locations where angel sharks (Squatinidae, $n=2315$ ) were captured during 7 fishery-independent surveys conducted in the western North Atlantic Ocean between 1950 and 2016. Numbers indicate key geographic locations mentioned in the text: 1=Nova Scotia, Canada; $2=$ Maine; $3=$ New Hampshire; 4=Massachusetts (MA); 5=Cape Cod, MA; 6=Martha's Vineyard, MA; 7=Rhode Island; 8=Connecticut; $9=$ New York; 10=New Jersey; 11=Philadelphia, Pennsylvania; $12=$ North Carolina (NC); 13=Cape Hatteras, NC; 14=Cape Lookout, NC; 15=South Carolina; 16=Georgia; 17=Florida (FL); 18=Jupiter and Port St. Lucie, FL; 19=Florida Keys; 20=Mississippi River Delta; 21=Mississippi Canyon; 22=Louisiana; and 23=Brownsville, Texas. 


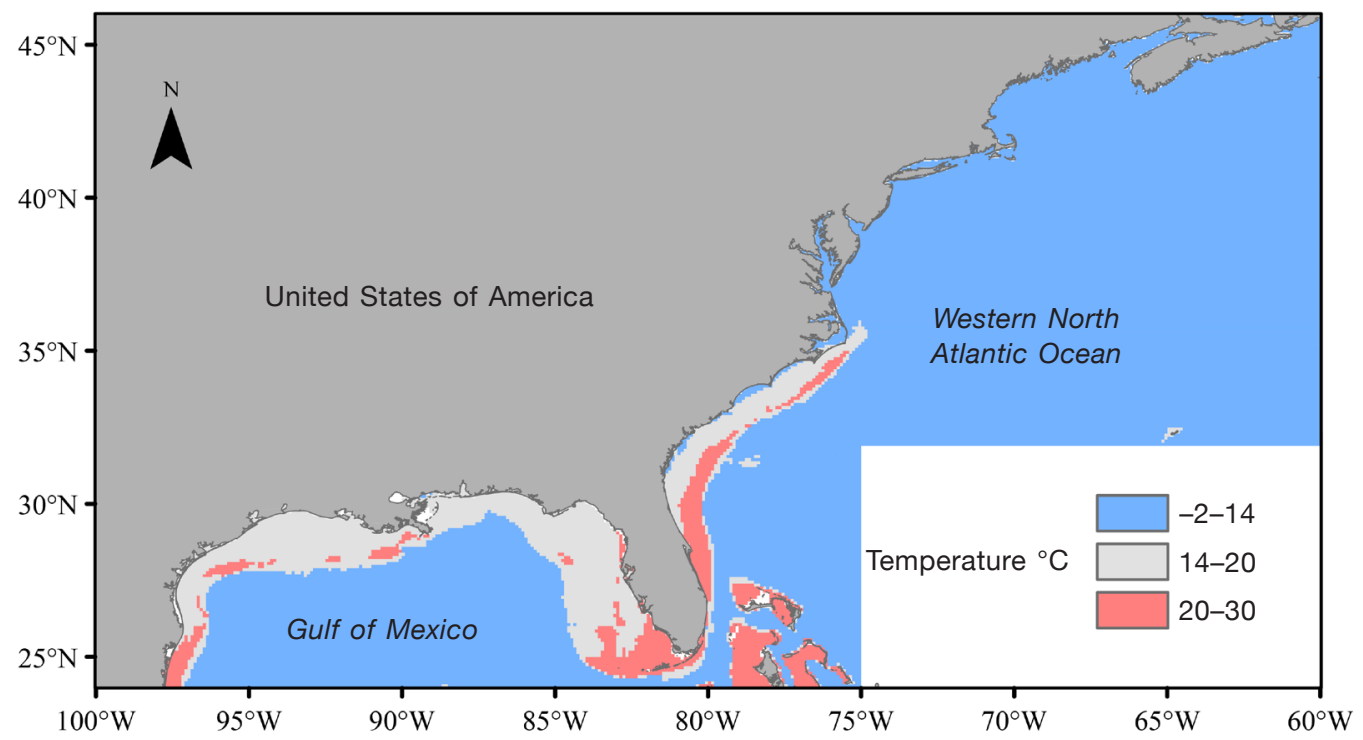

Figure 6

Bottom temperatures $\left({ }^{\circ} \mathrm{C}\right)$ associated with winter months (January, February, and March) off the coast of the southeastern United States and throughout the northern Gulf of Mexico, based on data from the NOAA National Centers for Environmental Information (northwest Atlantic Ocean, website; Gulf of Mexico, website).

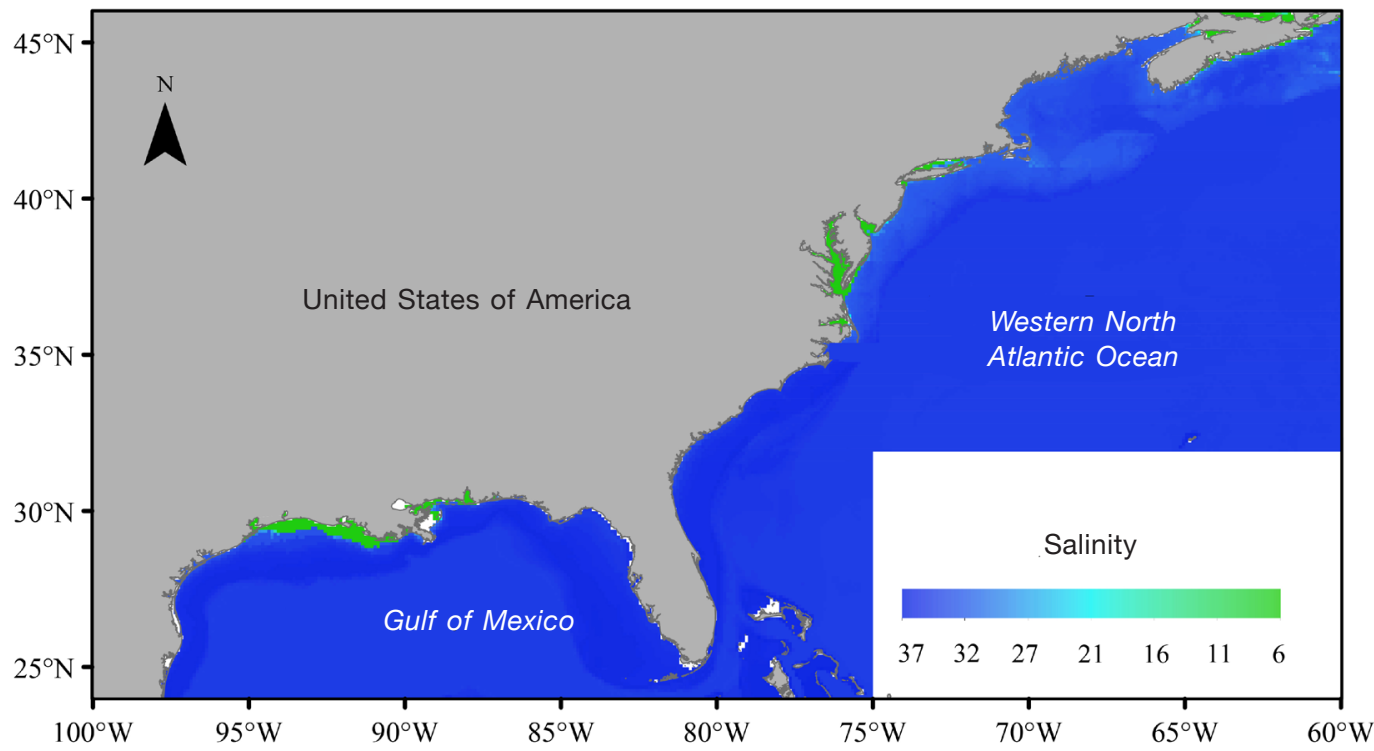

Figure 7

Annual composite of bottom salinity off the east coast of the southeastern United States and throughout the northern Gulf of Mexico based on data from the NOAA National Centers for Environmental Information (northwest Atlantic Ocean, website; Gulf of Mexico, website).

curring from New England to southern Florida (e.g., Compagno, 1984; McEachran and Fechhelm, 1998; Castro, 2011; Ebert et al., 2013). The results of our study indicate that angel sharks in US waters of the WNA have a discontinuous distribution with gaps approximately from Georgia through Florida, off the EC, and across the Mississippi Canyon in the GOM. The first assessment of the distribution of Squatina in the
WNA is attributable to Jordan (1885) who considered the angel shark (S. squatina, with $S$. dumeril considered a junior synonym at the time) to occur only off the northeastern United States. Several years later, Jordan and Evermann (1896) reported this species occurring "from Cape Cod southward." However, within the junior synonym list, the authors state the location of the source material for the original description of 
S. dumeril by Le Sueur (1818) was "probably Florida." Similarly, Bigelow and Schroeder (1948) stated that one of the original specimens examined by Le Sueur (1818) in his original description of the species was possibly collected off of eastern Florida.

The speculations of Jordan and Evermann (1896) and Bigelow and Schroeder (1948) were almost certainly based on one of Le Sueur's syntypes that were collected by Titian Peale, an artist and naturalist, who participated in the 1817 Florida Expedition of the Academy of Natural Sciences of Philadelphia (ANSP). The description of $S$. dumeril by Le Sueur (1818) was based on three specimens. Although Le Sueur (1818) did not specifically state where these specimens were collected, the syntype accessioned in the Museum National D'Histoire Naturelle (MNHN-IC-A-9692), by Le Sueur himself, lists New York as the locality of collection. Le Sueur (1818) wrote "My observations on this species are derived from three individuals, perfectly alike; and the drawing was made from one which Mr. Titian Peale kindly put into my hands for examination, before preparing it for the museum." Peale, who was from Philadelphia, Pennsylvania, took his first collecting trip abroad during the 1817 ANSP Florida Expedition, which lasted from 25 December 1817 until late April 1818 (Porter, 1983, 1985; Bennett, 2002); however, Le Sueur's description of $S$. dumeril, which included the specimen provided by Peale, was read to the ANSP on 3 March 1818 (Le Sueur, 1818). Because Peale did not return from his collecting trip in Florida until over a month after $S$. dumeril had been described by Le Sueur, and because Peale's detailed logs do not mention the collection of any sharks; the specimen in question was therefore not collected as part of the ANSP Florida Expedition. Further, no angel sharks were collected during 12,451 trawls conducted south of $32.93^{\circ} \mathrm{N}$ off the EC, an area extending from the central coast of South Carolina to the Florida Keys. Additionally, no angel sharks were reported within observer data collected during 942 commercial trawls for penaeid and rock shrimp that were conducted from Cape Hatteras, North Carolina $\left(35.20^{\circ} \mathrm{N}\right)$ to Port St. Lucie, Florida $\left(\sim 27.0^{\circ} \mathrm{N}\right)$ from 2007 to 2010 (Scott-Denton et al., 2012). However, 2 records of angel sharks having been captured and tagged by recreational fishermen in shallow water off the east coast of Florida are present within the NMFS Cooperative Shark Tagging Program database $\left(\right.$ Kohler $\left.^{5}\right)$. One shark was tagged off Ponte Vedra Beach, Florida, on 17 June 1973 and the other near Fort Lauderdale, Florida, on 3 October 1979. Both sharks were caught off the EC at latitudes lower than those at which any angel sharks have been reported before or since. Further, because there is no way to verify identifications of these specimens (i.e., photographs) and because angel sharks are morphologically similar (e.g., dorsoventrally depressed,

\footnotetext{
${ }^{5}$ Kohler, N. 2018. Personal commun. Northeast Fish. Sci. Cent., Natl. Mar. Fish. Serv., NOAA, 28 Tarzwell Dr., Narragansett, RI 02882.
}

two relatively large dorsal fins) to the lesser electric ray (Narcine bancroftii), which commonly occurs off the east coast of Florida (McEachran and de Carvalho, 2002), we suspect these records are anomalies or the result of misidentification.

The northern extent of the distribution of Atlantic angel sharks was recently reported by Ebert et al. (2013) to extend into New England waters (i.e., Connecticut, Rhode Island, Massachusetts, New Hampshire, and Maine). However, the northernmost documented occurrence of the Atlantic angel shark off the EC that we are aware of is off Massachusetts (e.g., Smith, 1922), which is the northern distribution extent of Atlantic angel sharks acknowledged by Castro (1983) and Compagno (2002). Additionally, no angel sharks were collected during 15,074 NEFSC trawls conducted north of Martha's Vineyard, Massachusetts $\left(\sim 41.5^{\circ} \mathrm{N}\right)$. Furthermore, among all survey data examined for our study, no Atlantic angel sharks were collected north of southern New Jersey $\left(39.30^{\circ} \mathrm{N}\right)$ and only $2.6 \%$ of all angel sharks collected during fishery-independent surveys off the EC were found south of Cape Lookout, North Carolina $\left(34.58^{\circ} \mathrm{N}\right)$. Therefore, we conclude that the primary range of Atlantic angel sharks off the EC of the US extends from southern New Jersey to Cape Lookout, North Carolina.

The distribution of angel sharks off the EC appears to be temperature driven because this variable had the highest level of significance in the logistic models. Off the EC, the Labrador Current brings relatively cool water southward from northern latitudes, terminating near Cape Hatteras, North Carolina at $\sim 35.2^{\circ} \mathrm{N}$ (Fratantoni and Pickart, 2007). North of Cape Hatteras, angel sharks are present year-round; however, south of this area in the waters of southern North Carolina and northern South Carolina, the species occurs offshore in relatively deep waters during winter. From December through March, the mean bottom temperature of inshore waters from Cape Hatteras to Charleston, South Carolina, is less than $13^{\circ} \mathrm{C}$ (Grieve et al., 2016), below the minimum preferred temperature for angel sharks $\left(13.5^{\circ} \mathrm{C}\right)$. By February, mean bottom temperatures of these coastal waters are less than $12^{\circ} \mathrm{C}$ south of Cape Lookout, North Carolina (Atkinson et al., 1983). Although water temperatures in offshore waters along much of the continental shelf in the region are within the preferred temperature range of angel sharks during the winter, the influx of warm waters from the Florida Current during this time results in bottom temperatures above the preferred temperature $\left(19.5^{\circ} \mathrm{C}\right)$ of angel sharks south of central Florida (Fig. 6; Atkinson et al., 1983; Grieve et al., 2016). Therefore, we hypothesize that a thermal barrier prevents angel sharks inhabiting waters off the EC from moving into the GOM.

Temperature also limits the movement of angel sharks from the GOM into waters within the Straits of Florida and northward along the EC. The preferred water temperature of angel sharks in the GOM was found to be $15.7-19.4^{\circ} \mathrm{C}$. However, mean annual tem- 
peratures in relatively shallow waters of the Dry Tortugas and Florida Keys are in excess of $24^{\circ} \mathrm{C}$ (Lee and Williams, 1999),-temperatures above the preferred temperature range for angel sharks. Therefore, if angel sharks do occur in shallow waters of the eastern GOM, the relatively high water temperatures of the Dry Tortugas and Florida Keys year-round could act as a barrier for angel shark movement into the Straits of Florida. To our knowledge, the only record of angel sharks occurring in shallow waters of the eastern GOM is attributable to Fowler (1906) who stated that local fishermen reported Rhina squatina (a junior synonym for $S$. dumeril) was "occasionally taken in summer" in the Florida Keys. Because of the morphological similarity between angel sharks and guitarfishes (Rhinobatidae) and because the Atlantic guitarfish (Pseudobatos lentiginosus) is "often encountered in shallow waters around the Florida Keys" (Bigelow and Schroeder, 1953), we believe Fowler's (1906) report of angel sharks occurring in the area to be in error.

South of the Dry Tortugas, the South Florida Escarpment is within the preferred depth range for angel sharks and could represent a relatively narrow corridor through which angel sharks could move from the GOM into the Florida Straits. Additionally, based on our data (Fig. 6) and on visual inspection of temperature data presented by Soto (1985), bottom temperature on the South Florida Escarpment at depths between approximately 150 and $250 \mathrm{~m}$ is within the preferred temperature range of angel sharks during a portion of the year. However, Longley and Hildebrand (1941) did not list angel sharks among the fishes collected in dredges conducted across the South Florida Escarpment, south of the Dry Tortugas, and on the Tortugas Terrace, despite having documented other shark species, such as the chain dogfish (Scyliorhinus retifer) and Caribbean lanternshark (Etmopterus hillianus). Additional sampling will be required to determine whether angel sharks are present within the Straits of Florida, particularly along the South Florida Escarpment and on the Pourtales Terrace where bottom temperatures are within the preferred range of this species.

Velocity and direction of the Florida Current as it moves through the Straits of Florida and changes trajectory to the north off the southeastern tip of Florida are other possible mechanisms acting, possibly in concert with temperature, to limit movements of angel sharks between the EC and GOM. Although information on the swimming performance of Atlantic angel sharks is scant, Standora and Nelson (1977) examined the diel activity patterns of Pacific angel sharks (S. californica) associated with Santa Catalina Island, California. The authors concluded the species is relatively sedentary during daylight hours and becomes more active at night. Mean sustained swimming speeds during nocturnal periods were approximately $11 \mathrm{~cm} / \mathrm{s}$ and maximum reported sustained swimming speed was approximately $25 \mathrm{~cm} / \mathrm{s}$. Lee et al. (1992) deployed an acoustic Doppler current profiler to a depth of $200 \mathrm{~m}$ in the Straits of Florida south of Looe Reef and recorded bottom currents up to $40 \mathrm{~cm} / \mathrm{s}$. Hamilton et al. (2005) analyzed data from buoy arrays moored off Jupiter in southeastern Florida and reported current speeds of over $70 \mathrm{~cm} / \mathrm{s}$ at a depth of $300 \mathrm{~m}$. Relatively high bottom current speeds and seasonal bottom current reversals (e.g., Düing and Johnson, 1972), coupled with the comparatively low maximum sustained swimming speed of angel sharks, could make the Straits of Florida energetically demanding to traverse and thus a potential barrier for exchange between basins.

Unlike angel sharks off the EC, angel sharks were not collected inshore in the GOM during fishery-independent surveys despite extensive sampling efforts in shallow waters. However, of the 60,827 commercial shrimp trawl catches sampled by fishery observers from 1981 through 2015 in the GOM from January to April, angel sharks were observed in 9 trawls conducted at depths less than $70 \mathrm{~m}\left(\mathrm{Hart}^{6}\right)$. Furthermore, an experienced commercial shark fisherman provided photographs of an angel shark captured in nearshore waters of the northern GOM during the winter of 2018 and reported frequent captures of angel sharks in gill nets off Mississippi and Alabama at depths as shallow as $18 \mathrm{~m}$ during winter months of January and February (Stiller ${ }^{7}$ ). Therefore, more sampling will be needed in the northern GOM during winter months to fully describe seasonal variability in the depth range of angel sharks within the region.

Angel sharks were collected throughout the northern GOM. However, in an area off Louisiana, between the Mississippi River Delta and the western edge of Mississippi Canyon, only 2 individuals were collected over the 67-year sampling period, despite 3600 trawls conducted in that area during that period. This hypothesized discontinuity in distribution could be related to a number of factors, including the steepness of the narrow shelf at the terminus of the Mississippi Delta, upwelling of cold water through the Mississippi Canyon, or abiotic conditions related to discharge from the Mississippi River. A similar discontinuity in the distribution and genetic population structure of blacknose sharks (Carcharhinus acronotus) associated with the same area was identified by Portnoy et al. (2014) using molecular techniques. The authors speculated that the freshwater plume associated with the Mississippi River potentially acts as a physiological barrier between the eastern and western GOM for stenohaline species. Like blacknose sharks, angel sharks in the GOM appear to be stenohaline because they were collected in a narrow range of preferred salinity (i.e., 34.7-36.3). Future research will be needed to address the discontinuity in distribution in this region and whether it is related to salinity.

\footnotetext{
${ }^{6}$ Hart. R. 2016. Unpubl. data. Southeast Fish. Sci. Cent., Natl. Mar. Fish. Serv., NOAA, 4700 Ave. U, Bldg. 306, Galveston, TX 77551.

${ }^{7}$ Stiller, D. 2018. Personal commun. Commercial fisherman.
} 
The spatial disjunction of squatinid sharks between the EC and the GOM suggests the possibility of genetic isolation between angel sharks in the 2 regions. Therefore, we hypothesize that squatinid sharks in the GOM and the EC are separate evolutionary units. Although current research cannot address the species status of squatinid sharks in US waters of the WNA, our findings do suggest an evaluation is warranted. Further, on the basis of the presence of what appears to be a distributional break at the Mississippi River Delta/Mississippi Canyon, we hypothesize that squatinids in the eastern and western GOM represent, at a minimum, 2 separate populations. As human activities intensify in offshore waters of the GOM (e.g., commercial fishing, petroleum industry), it will become increasingly imperative to understand the species composition and population structures of marine organisms in poorly studied areas so that conservation efforts can effectively mitigate potentially deleterious effects.

\section{Acknowledgments}

We thank J. Gartland (Virginia Institute of Marine Science), R. Hart (NMFS), P. Kostovick (NMFS), and T. Smart (South Carolina Department of Natural Resources) for providing data from various surveys. We also thank the numerous persons who spent an extraordinary amount of time at sea collecting the data used in our study.

\section{Literature cited}

Applegate, S. P., L. Espinosa, L. Menchaca, and F. Sotelo. 1979. Tiburones Mexicanos, $146 \mathrm{p}$ Subsecretaria de Educacion e Investigacidn Tecnolbgica, Dirección General de Ciencias y Tecnologia del Mar, Mexico City, Mexico.

Atkinson, L. P., T. N. Lee, J. O. Blanton, and W. S. Chandler. 1983. Climatology of the southeastern United States continental shelf waters. J. Geophys. Res., C 88:47054718. Article

Baremore, I. E.

2010. Reproductive aspects of the Atlantic angel shark Squatina dumeril. J. Fish Biol. 76:1682-1695. Article

Bennett, T. P.

2002. The 1817 Florida Expedition of the Academy of Natural Sciences. Proc. Acad. Nat. Sci. Phila. 152:1-21. Article

Bigelow, H. B. and W. C. Schroeder.

1948. Sharks. In Fishes of the western North Atlantic. Part one: lancelets, cyclostomes, sharks (A. E. Parr and Y. H. Olsen, eds.), p. 59-546. Mem. Sears Found. Mar. Res., Yale Univ., New Haven, CT.

1953. Sawfishes, guitarfishes, skates and rays. In Fishes of the western North Atlantic. Part two: sawfishes, guitarfishes, skates, rays, and chimaeroids (A. E. Parr and Y. H. Olsen, eds.) p. 1-514. Mem. Sears Found. Mar. Res., Yale Univ., New Haven, CT.

Castro, J. I.

1983. The sharks of North American waters, 180 p. Texas A\&M Univ. Press, College Station, TX.
2011. The sharks of North America, 640 p. Oxford Univ. Press, Oxford, UK.

Castro-Aguirre, J. L., H. E. Pérez, and L. H. Campos.

2006. Dos nuevas especies del género Squatina (Chondrichthyes: Squatinidae) del Golfo de México. Rev. Biol. Trop. 54:1031-1040.

Colonello, J. H., L. O. Lucifora, and A. M. Massa.

2007. Reproduction of the angular angel shark (Squatina guggenheim): geographic differences, reproductive cycle, and sexual dimorphism. ICES J. Mar. Sci. 64:131-140. Article

Compagno, L. J. V.

1984. FAO species catalogue. Vol. 4. Sharks of the world. An annotated and illustrated catalogue of shark species known to date. Part 1. Hexanchiformes to Lamniformes. FAO Fish. Synop. 125, 249 p. FAO, Rome.

2002. Sharks. In The living marine resources of the Western Central Atlantic. Vol. 1: introduction, molluscs, crustaceans, hagfishes, sharks, batoid fishes, and chimaeras. FAO species identification guide for fishery purposes and American Society of Ichthyologists and Herpetologists Spec. Publ. 5 (K. E. Carpenter, ed.), p. 357-505. FAO, Rome.

Compagno, L., M. Dando, and S. Fowler.

2005. Sharks of the world, 368 p. HarperCollins Publishers, London.

Düing, W., and D. Johnson.

1972. High resolution current profiling in the Straits of Florida. Deep-Sea Res. 19:259-274. Article

Dulvy, N. K., S. L. Fowler, J. A. Musick, R. D. Cavanagh, P. M. Kyne, L. R. Harrison, J. K. Carlson, L. N. K. Davidson, S. V. Fordham, M. P. Francis, et al.

2014. Extinction risk and conservation of the world's sharks and rays. eLife 3:e00590. Article

Ebert, D. A., S. Fowler, and L. Compagno.

2013. Sharks of the world: a fully illustrated guide. Wild Nature Press, Plymouth, UK.

Fowler, H. W.

1906. Some cold-blooded vertebrates of the Florida Keys. Proc. Acad. Nat. Sci. Phila. 58:77-113.

Fratantoni, P. S., and R. S. Pickart.

2007. The western North Atlantic shelfbreak current system in summer. J. Phys. Oceanogr. 37:2509-2533. Article

Grieve, B. D., E. N. Curchitser, and R. R. Rykaczewski.

2016. Range expansion of the invasive lionfish in the northwest Atlantic with climate change. Mar. Ecol. Prog. Ser. 546:225-237. Article

Hamilton, P., J. C. Larsen, K. D. Leaman, T. N. Lee, and E. Waddell.

2005. Transports through the Straits of Florida. J. Phys. Oceanogr. 35:308-322. Article

Jordan, D. S.

1885. A catalogue of the fishes known to inhabit the waters of North America, north of the Tropic of Cancer, with notes on the species discovered in 1883 and 1884, 185 p. U.S. Gov. Print. Off., Washington, D. C.

Jordan, D. S., B. D. Evermann.

1896. The fishes of North and Middle America: a descriptive catalogue of the species of fish-like vertebrates found in the waters of North America, north of the Isthmus of Panama. Part I. Bull. U. S. Natl. Mus. 47, 1240 p.

Lee, T. N., and E. Williams.

1999. Mean distribution and seasonal variability of coastal currents and temperature in the Florida Keys with 
implications for larval recruitment. Bull. Mar. Sci. 64:35-56.

Lee, T. N., C. Rooth, E. Williams, M. McGowan, A. F. Szmant, and M. E. Clarke.

1992. Influence of Florida Current, gyres and wind-driven circulation on transport of larvae and recruitment in the Florida Keys coral reefs. Cont. Shelf Res. 12:971-1002. Article

Le Sueur, C. A.

1818. Descriptions of several new species of North American fishes. J. Acad. Nat. Sci. Phila. 1:222-235.

Longley, W. H., and S. F. Hildebrand.

1941. Systematic catalogue of the fishes of Tortugas, Florida. Carnegie Inst. Wash. Publ. 535, 331 p. Carnegie Inst. Wash., Washington, D.C.

Magnuson, J. J., L. B. Crowder, and P. A. Medvick.

1979. Temperature as an ecological resource. Am. Zool. 19:331-343. Article

McEachran, J. D., and J. D. Fechhelm.

1998. Fishes of the Gulf of Mexico. Vol. 1: Myxiniformes to Gasterosteiformes, 1120 p. Univ. Texas Press, Austin, TX.

McEachran, J. D., and M. R. de Carvalho.

2002. Batoid fishes. In The living marine resources of the Western Central Atlantic. Vol. 1: introduction, molluscs, crustaceans, hagfishes, sharks, batoid fishes, and chimaeras. FAO species identification guide for fishery purposes and American Society of Ichthyologists and Herpetologists Spec. Publ. 5. (K. E. Carpenter, ed.), p. 507-590. FAO, Rome.

Portnoy, D. S., C. M Hollenbeck, C. N. Belcher, W. B. Driggers III, B. S. Frazier, J. Gelsleichter, R. D. Grubbs, and J. R. Gold.

2014. Contemporary population structure and post-glacial genetic demography in a migratory marine species, the blacknose shark, Carcharhinus acronotus. Mol. Ecol. 23:5480-5495. Article
Porter, C. M.

1983. Following Bartram's “track": Titian Ramsay Peale's Florida journey. Fla. Hist. Q. 61:431-444.

1985. The lifework of Titian Ramsay Peale. Proc. Am. Philos. Soc. 129:300-312.

Scott-Denton, E., P. F. Cryer, M.R. Duffy, J. P. Gocke, M. R. Harrelson, D. L. Kinsella, J. M. Nance, J. R. Pulver, R. C. Smith, and J. A. Williams.

2012. Characterization of the U.S. Gulf of Mexico and South Atlantic penaeid and rock shrimp fisheries based on observer data. Mar. Fish. Rev. 74(4):1-27.

Smith, H. M.

1922. Second occurrence of Squatina in New England. Copeia 106:33.

Soto, L. A.

1985. Distributional patterns of deep-water brachyuran crabs in the Straits of Florida. J. Crustac. Biol. 5:480-499. Article

Standora, E. A., and D. R. Nelson.

1977. A telemetric study of the behavior of free-swimming Pacific angel sharks, Squatina californica. Bull. South. Calif. Acad. Sci. 76:193-201.

Tagliafico, A., S. Rangel, and M. K. Broadhurst.

2017. Reproductive aspects of the Atlantic angel shark Squatina dumeril in the southern Caribbean Sea. J. Fish Biol. 91:1062-1071. Article

Vaz, D. B. F. and de Carvalho, M .R.

2013. Morphological and taxonomic revision of species of Squatina from the southwestern Atlantic Ocean (Chondrichthyes: Squatiniformes: Squatinidae). Zootaxa 3695:1-81. Article

Walsh, J. H., and D. A. Ebert.

2007. A review of the systematics of western North Pacific angel sharks, genus Squatina, with redescriptions of Squatina formosa, S. japonica, and S. nebulosa (Chondrichthyes: Squatiniformes, Squatinidae). Zootaxa 1551:31-47. 